\title{
Efficacy and long-term evaluation of intramyocardial injection of autologous CD34-enriched PBMSC in old myocardial infarction*
}

\author{
José Luis Aceves ${ }^{1}$, Abel Archundia ${ }^{1}$, Araceli Páez ${ }^{2}$, Rafael Vilchis ${ }^{1}$, Elvira Varela ${ }^{2}$, Emma Rodriguez $^{2}$, \\ Guillermo Diaz ${ }^{1}$, Lourdes Flores-Luna ${ }^{3}$, Martha Alvarado ${ }^{4}$, Manuel Lopez Hernandez ${ }^{4}$, \\ Luis Felipe Montaño ${ }^{5}$, Felipe Masso ${ }^{2 \#}$ \\ ${ }^{1}$ Department of Cardiovascular Surgery, National Medic Center 20 de Noviembre ISSSTE, Mexico City, Mexico \\ ${ }^{2}$ Department of Cellular Physiology, National Institute of Cardiology “Ignacio Chavez”, Mexico City, Mexico \\ ${ }^{3}$ Center of Population Health Research, National Institute of Public Health, Mexico City, Mexico \\ ${ }^{4}$ Department of Hematology, National Medic Center 20 de Noviembre ISSSTE, Mexico City, Mexico \\ ${ }^{5}$ Immunobiology Laboratory, Department of Cell and Tissue Biology, School of Medicine UNAM, Mexico City, Mexico \\ Email: $\underline{\text { f_masso@yahoo.com }}$
}

Received 2 June 2012; revised 6 July 2012; accepted 13 July 2012

\begin{abstract}
Aims: We have shown that autologous transplant of CD34 $^{+}$-enriched peripheral-blood mononuclear cells (PBMSC) could restore depressed myocardial function, and sustain adequate myocardial function 12 months after surgery in patients with old ( $>$ one yearold) myocardial infarction. Our aim is to report the long-term morbidity and mortality efficacy of this procedure. Methods and results: Seventy patients with an old anteroseptal myocardial infarction were followed for 2 to 7 years, 35 had a revascularization procedure and received an intra-myocardial injection of autologous $\mathrm{CD}^{+}{ }^{+}$-enriched PBMSC $\left(8 \times 10^{8}\right.$ mononuclear cells $/ \mathrm{ml}$ including $3 \times 10^{7} \mathrm{CD34}^{+}$cells $\left./ \mathrm{ml}\right)($ Group A). Group B patients only had the revascularization. Abnormal pre-surgical values of LVEF $(33.2 \% \pm 4.8 \%)$, LVDV $(178 \pm 13.7 \mathrm{ml})$, LVSV $(120 \pm 16 \mathrm{~m})$, LVDD $(58.9 \pm 3.84 \mathrm{~mm}), E$ and $A$ waves without contractility in infarction area in group $A$ patients improved to approximate normal values $(50 \% \pm 3 \%$ for LVEF; $90 \pm$ $9.3 \mathrm{ml}$ for LVDV; $80 \pm 9.9 \mathrm{ml}$ for LVSV; $55.3 \pm 3 \mathrm{~mm}$ for LVDD; $5.2 \pm 0.5 \mathrm{~cm} / \mathrm{s}$ for $E$ wave and $4.18 \pm 0.3$ $\mathrm{cm} / \mathrm{s}$ for A wave) 1 year after the procedure and have remained unaltered for all the follow-up period. All the patients remain alive. Only seven patients have been readmitted to the hospital for non-myocardial related events. Group B only 11 patients continued alive to 5 years after surgery and LEVF never increased more than $6 \%$, all of them with many hospitalizations
\end{abstract}

\footnotetext{
*This work was supported by Consejo Nacional de Ciencia y Tecnologia Mexico (grant numbers SALUD-2002-CO1-7630, SALUD-2008-CO187707) and Universidad Nacional Autónoma de México (grant DGAPAPAPITT-202508-3).

\#Corresponding author.
}

( $n \geq 10)$ by heart failure events. Conclusion: Intramyocardial injection of $\mathrm{CD}^{+} 4^{+}$highly enriched PBSC represent an encouraging alternative for patients with severely scarred and dysfunctional myocardium.

Keywords: Stem Cells; Myocardial Infarction; CD34 ${ }^{+}$ Cells; Revascularization; Heart Failure; Ventricular Function

\section{INTRODUCTION}

Myocardial infarction is a main cause of mortality and morbidity in Western societies. The intracoronary injection of autologous bone marrow stem progenitor cells in acute or sub-acute lesions with viable tissue improves hemodynamic criteria and cardiac function [1,2]. Intracoronary infusion of peripheral blood mononuclear stem cells (PBMSC) mobilized by Granulocyte-Colony Stimulating Factor (G-CSF) in acute myocardial infarction [3] generates peri-stent tissue growth and a modest increase in cardiac function [4,5]. The beneficial effects, cardiac repair and restraint fibrosis, may be the result of increased angiogenesis and the production of cytokines from endothelial progenitors [6]. The delivery of progenitor cells into ischaemic cardiac muscle improves angiogenesis and revascularization [7].

The potential benefits and final outcome of stem cell transplantation in patients with old ( $>1$ year) myocardial infarction require further evaluation. One trial reports the results of the intracoronary application of unfractionated BMSC, mobilized with G-CSF, in patients with old myocardial infarction [8]. We have previously shown improved ventricular function in patients with old myocardial infarction subjected to the peri-infarction inject- 
tion of unfractionated PBMSC [9]. The aim of this paper was to report the long-term feasibility and safety of our process as well as to determine if depressed myocardial function is restored and sustains an adequate myocardial function for extended periods of time.

\section{METHODS}

\subsection{Patients}

Seventy patients (Mean age of $54.3 \pm 8.5$-year-old) with ischemic cardiomyopathy and more than one-year-old anteroseptal myocardial infarction (43.4 \pm 14.7 months) were eligible for inclusion into the study. They all had left ventricular failure as determined by the low left ventricular ejection fraction (LVEF) value, were considered as NYHA-III/IV functional class and were being treated with appropriate doses of angiotensin converting enzyme inhibitors, AT1R blockers, beta blockers and statins before the surgical procedure. The presence and extent of the infarct was determined by ECG, angiography (C type proximal injury in the left anterior descending coronary artery and akinesia in the anterior wall and apical heart zones), transthoracic echocardiogram (akinesia in the apex and the anterior myocardial side) and radionuclide myocardial perfusion imaging (old transmural infarction in the anterior wall and apical zone without evidence of viable tissue according to 201-Thalium rest, stress and 24 hour redistribution images). All the patients were candidates for a revascularization of the anterior descendent artery, and were divided into two groups. Group A individuals gave their informed consent for the revascularization procedure and the injection of their autologous CD34-enriched cell fraction, whereas group B included the individuals who only accepted the revascularization procedure and placebo (Physiologic solution). We only considered individuals with lesion in the anterior descending artery, since the possible inclusion of individuals having occlusion of the other arteries could bias our study. Each patient was evaluated every six months for the first year after surgery and then yearly. The ethics review board of the Hospital approved the protocol in January 2002, and the study was conducted in accordance with the Declaration of Helsinki.

\subsection{Surgical Procedure and Follow Up}

Our original stem cell protocol [9] was used in every patient. Briefly, patients are treated with G-CSF (Filgistrin, Neupogen ${ }^{\mathrm{TM}}$; $300 \mathrm{mg} /$ day) subcutaneously for five days. On the fifth day, a Mahurkar catheter is inserted into the subclavian artery and mononuclear cells are harvested with a close circuit in the apheresis machine. The percentage of $\mathrm{CD}_{3} 4^{+}$cells is then estimated by cytofluorometry before the $\mathrm{CD} 34^{+}$enriched with mononu- clear cells are cryopreserved at a ratio 1:1 with patient plasma. The revascularization procedure was always performed from the left internal thoracic artery to the anterior descending coronary artery with beating heart, that is, without extracorporeal circulatory support. Group A patients were subjected to the surgical procedure $48 \mathrm{hr}$. After that mononuclear cells were harvested. Once the revascularization procedure was finished, group A patients received $20 \mathrm{ml}$ of their autologous $\mathrm{CD}^{+} 4^{+}$enriched mononuclear cell preparation $\left(8 \times 10^{8}\right.$ mononuclear cells/ml including $3 \times 10^{7} \mathrm{CD} 34^{+}$cells/ml) distributed in $10 \times 2 \mathrm{ml}$ radial injections (2 inches deep) from the center of the scar to the border zone between healthy and infarcted tissue, following the course of the anterior descending coronary artery, thus assuring that the anterior wall and septum receive the CD34-enriched cells. None of the patients developed arrhythmia during or after the surgical procedure. Group B Patients received revascularization procedure and $20 \mathrm{ml}$ of physiological solution (Placebo) in the same manner in which the cells were implanted in group A.

After surgery the patients were monitored at 6 and 12 months, and then, yearly by tissue doppler and standard transthoracic echocardiography. The hemodynamic parameters included heart motility, left ventricular ejection fraction (LVEF), left ventricular end diastolic volume (LVDV), left ventricular end systolic volume (LVSV), left-ventricular end diastolic diameter (LVDD), mitral ring velocity, $\mathrm{E}$ and $\mathrm{A}$ wave in zone infarction. Tc 99 and 201-Thallium SPECT were made in each post-surgery evaluation.

Statistical analysis. The results were evaluated with non-parametric analysis using Prisma software; survival tables and graphs were done using STATA v.9 software. A p value $<0.05$ was considered statistically significant.

\section{RESULTS}

Mean age of group A patients (51.91 \pm 8.9-year-old) was lower than those in group B (56.86 \pm 8.1-year-old; $\mathrm{p}=$ 0.018 ) but the time interval between the acute infarct event and the first visit to us was significantly higher in group A vs group B patients ( $48.8 \pm 14.2$ months vs $38.1 \pm$ 15.2 months, $\mathrm{p}=0.004)$. Body mass index was lower in group A patients $\left(27.14 \pm 2.75\right.$ vs $29.31 \pm 2.81 \mathrm{Kg} / \mathrm{m}^{2}$; $\mathrm{p}=$ $0.0018)$. The follow-up period has been greater in group A patients $(61.97 \pm 54.65$ months vs $40.11 \pm 13.89$ months in group $\mathrm{B}, \mathrm{p}=0.015$ ).

Post-surgical complications were not reported in any of the patients. As surgical experience increased, the number of days the patients spent in the intensive care unit has diminished from 7 - 10 days, in the first five patients, to 3 - 5 days. Surgical experience also allowed us to choose patients with lower LVEF basal value $(40.2 \% \pm$ $3.7 \%$ for our first eight patients vs $33.4 \pm 4.8 \%$ for the 
subsequent; $\mathrm{p}=0.036)$.

The basal value of LVEF in group A and B patients was not significantly different. There was a highly significant difference between the LVEF basal value (35.06 \pm $5.44)$ and the six-months $(50.17 \pm 7.95$, p $<0.0001)$, one year $(51.03 \pm 7.57, \mathrm{p}<0.001)$ and $2-7$ years follow-up $(52.06 \pm 8.06 ; \mathrm{p}<0.0001)$ values in group A. Only three of group A patients had higher than $40 \%$ basal values (41\%, 41\% and 42\%) whereas six had basal values below $30 \%$ (25.3 $\pm 2.8 \%)$; interestingly. Two of the latter increased their LVEF percentage to values above the $40 \%$ limit after one year and have remained above that figure during the follow-up. The remaining four did not reach the $40 \%$ value but they increased their LVEF percentage by $17 \%, 32 \%, 36 \%$, and $71 \%$, compared to their basal value. In group B patients, the LVEF value remained almost unchanged six months after the revascularization (38 \pm 4.03 , p N.S.). The survival at five years was nil in group $B$ patients, those who remained alive one year after the revascularization only showed a $3 \%$ increase in the LVEF value.

Table 1 shows the basal and follow-up values of LVDV, LVSV and LVDD in groups A and B. A signifycant improvement was observed in group A patients six months after surgery. Figures $\mathbf{1}$ and $\mathbf{2}$ show the pre- and post-operative SPECT imaging of a representative patient of group A.

Table 2 shows the basal and follow up values of the $S$, $\mathrm{A}$ and $\mathrm{E}$ waves in both groups. Contraction in the injured tissue (S wave) improved significantly in group A patients after six months, one year and follow-up. Similar results were obtained for initial diastolic contraction ( $\mathrm{E}$ wave) and late telediastolic contraction (A wave) that also improved significantly from an initial value of 0 to $4.18 \pm 0.33 \mathrm{~cm} / \mathrm{seg}$ and $4.28 \pm 0.61 \mathrm{~cm} / \mathrm{seg}$ after six and 1 year. Similarly, mitral ring velocity improved from $4.7 \pm$ 0.51 to $8.48 \pm 1.04 \mathrm{~cm} / \mathrm{seg}$ and $8.62 \pm 1.10 \mathrm{~cm} / \mathrm{seg}(\mathrm{p}<$
0.0001) after six months and 1 year. Group B patients showed a slight increase in all the above-mentioned parameters but were not statistically significant. All the patients received medic treatment by cardiologist responsible in order to control of ischemia, hypertension, dyslipidemia and blood glucose.

Table 3 shows the post-surgery hospitalization episodes and their outcome in both groups. All group A patients are currently alive and none of them has been hospitalized again for heart failure. Group B mortality was $100 \%$ five years after revascularization; 16 of them die due to a second acute and extensive myocardial infarction within the first three years post-surgery; in the remaining 19 the cause of death was arrhythmia and/or complications of chronic cardiac failure. Figure 3 shows the survival rate in both groups.

\section{DISCUSSION}

We have previously reported the benefit of peri-infarction injection of, G-CSF mobilized, unfractionated peripheral blood stem cells in people with extensive vast scar tissue from an old heart infarction episode [9]. This work report our experience with patients followed for up to seven years.

Granulocyte-colony stimulating factor (G-CSF) mobilized peripheral-blood mononuclear $\mathrm{CD}^{+}{ }^{+}$stem cells (PBMSC) are used in acute myocardial infarcted patients $[8,10]$. The use of autologous bone marrow mononuclear stem cells in a canine model of chronic myocardial infarction has been associated with superior cardiac recovery [11]. We choose to applicate autologous CD34-enriched PBMSC intramyocardially in open heart surgery because stem cells are found in low quantities in old infarcted tissue, and because intracoronary perfusion doesn't guarantee the arrival of adequate number of cells into the damaged zone, and can induce restenosis [12].

Table 1. Echocardiographic values before and after treatment

\begin{tabular}{|c|c|c|c|c|c|}
\hline & Basal & 6 months & 1 year & $2-7$ years & p value \\
\hline \multicolumn{6}{|l|}{ LVDV } \\
\hline Group A & $178 \pm 13$ & $90 \pm 9.3$ & $93 \pm 15$ & $91 \pm 4$ & 0.0001 \\
\hline Group B & $162 \pm 16$ & $150 \pm 10$ & $155 \pm 9$ & $153 \pm 5$ & NS \\
\hline \multicolumn{6}{|l|}{ LVSV } \\
\hline Group A & $120 \pm 16$ & $80 \pm 9.9$ & $85 \pm 12.5$ & $83 \pm 8$ & 0.0001 \\
\hline Group B & $115 \pm 22$ & $111 \pm 10$ & $108 \pm 12$ & $110 \pm 10$ & NS \\
\hline \multicolumn{6}{|l|}{ LVDD } \\
\hline Group A & $58 \pm 3$ & $55 \pm 2$ & $54 \pm 3$ & $55 \pm 3$ & 0.0001 \\
\hline Group B & $57 \pm 2$ & $56 \pm 1$ & $55 \pm 3$ & $52 \pm 4$ & NS \\
\hline
\end{tabular}

Group A corresponds to the patients that received the CD34-enriched PBMSC fraction. Group B correspond to the patients that served as control. Group A and B patients had a revascularization procedure from the left internal thoracic artery to the left anterior descending coronary artery. LVDV = Left ventricular end diastolic volume. LVSV = Left ventricular end systolic volume. LVDD = Left ventricular end diastolic cavital diameter. Results are represented as the mean \pm standard error of the mean. N.S. = not significant. 


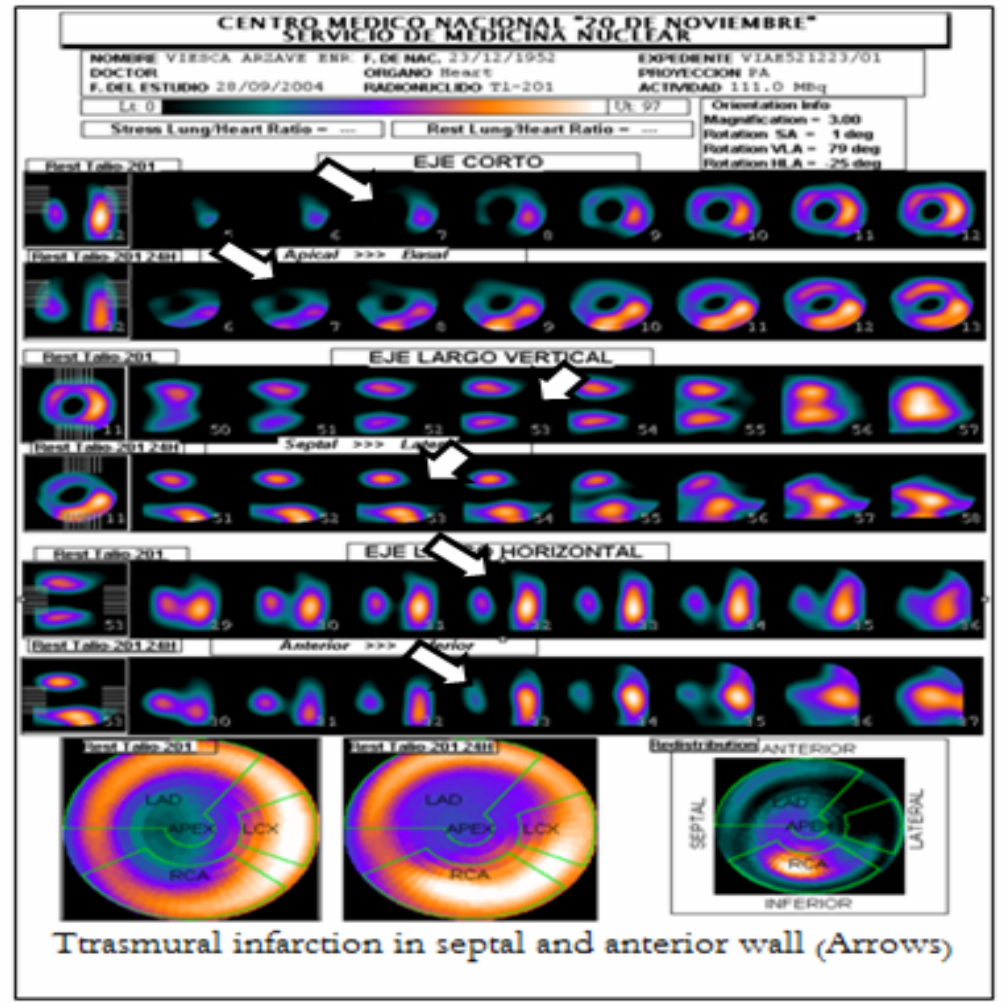

Figure 1. Representative SPECT of a patient before the intra-myocardial injection of autologous Bone Marrow Stem Cells.

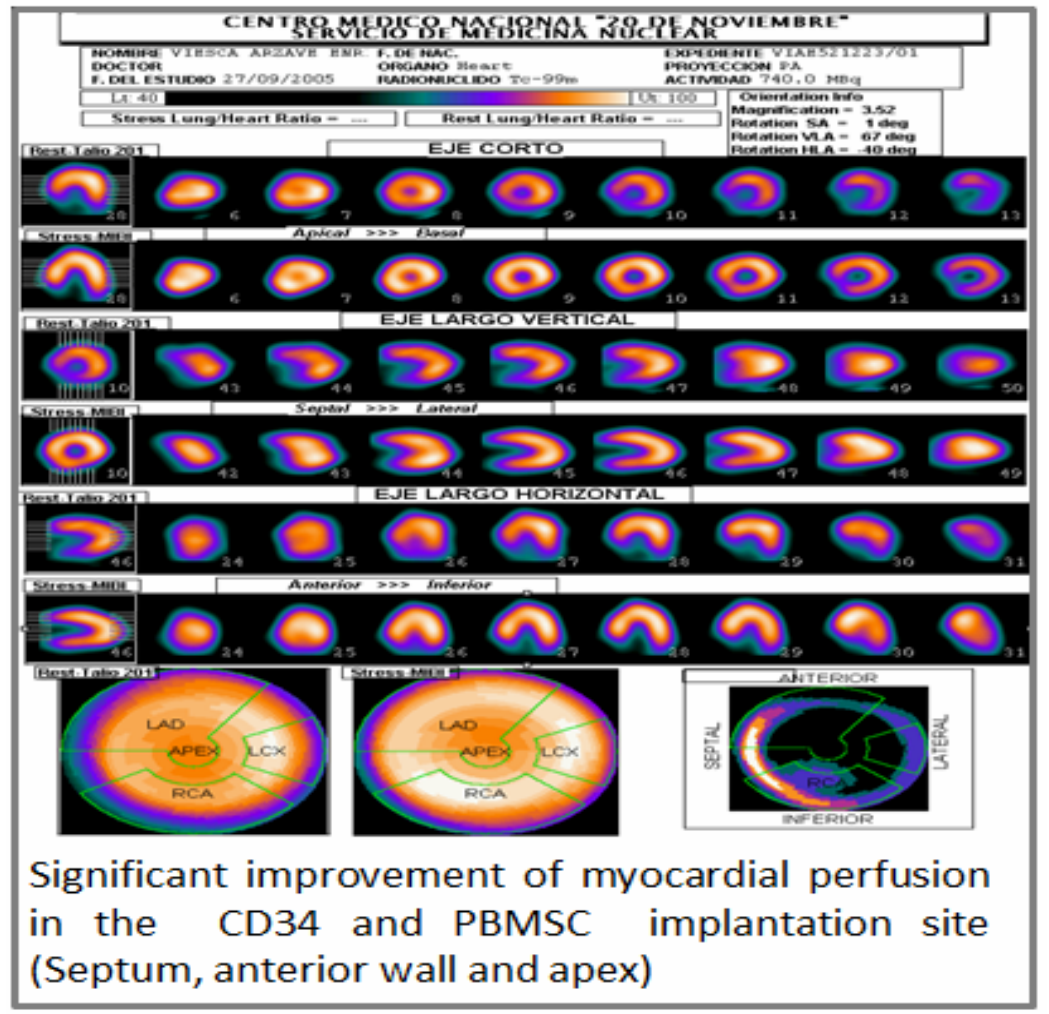

Figure 2. Image 12 months after intra-myocardial injection of autologous Bone Marrow Stem Cells in the same patient depicted in Figure 1. 
Table 2. Myocardial tissue contraction before and after treatment.

\begin{tabular}{|c|c|c|c|c|c|}
\hline & Basal & 6 months & 1 year & 2 - 7 years & $\mathrm{p}$ value \\
\hline \multicolumn{6}{|l|}{ S wave } \\
\hline Group A & 0 & $4.36 \pm 0.6$ & $4.43 \pm 0.58$ & $4.28 \pm 0.55$ & 0.0001 \\
\hline Group B & 0 & $2.03 \pm 0.9$ & $2.23 \pm 0.76$ & $2.51 \pm 0.68$ & NS \\
\hline \multicolumn{6}{|l|}{ E wave } \\
\hline Group A & 0 & $5.21 \pm 0.5$ & $5.25 \pm 0.4$ & $5.25 \pm 0.7$ & 0.0001 \\
\hline Group B & 0 & $2.13 \pm 0.2$ & $2.52 \pm 0.3$ & $2.71 \pm 0.5$ & NS \\
\hline \multicolumn{6}{|l|}{ A wave } \\
\hline Group A & 0 & $4.18 \pm 0.3$ & $4.28 \pm 0.6$ & $4.64 \pm 0.7$ & 0.0001 \\
\hline Group B & 0 & $2.37 \pm 0.5$ & $2.58 \pm 0.5$ & $2.88 \pm 0.6$ & NS \\
\hline \multicolumn{6}{|l|}{ MRV } \\
\hline Group A & $4.7 \pm 0.51$ & $8.48 \pm 1.04$ & $8.62 \pm 1.10$ & $8.51 \pm 1.23$ & 0.0001 \\
\hline Group B & $4.5 \pm 0.54$ & $4.71 \pm 0.52$ & $4.63 \pm 0.47$ & $4.89 \pm 0.31$ & NS \\
\hline
\end{tabular}

Group A corresponds to the patients that received the CD34-enriched PBMSC fraction. Group B correspond to the patients that served as control. Group A and B patients had a revascularization procedure from the left internal thoracic artery to the left anterior descending coronary artery. S wave = Contraction in the injured tissue; $\mathrm{E}$ wave = Initial diastolic contraction; A wave = Late telediastolic contraction; MRV = Mitral ring velocity. Results are represented as the mean \pm standard error of the mean. N.S. $=$ not significant.

Table 3. Post-surgery causes of new hospitalization events in group A patients.

\begin{tabular}{|c|c|c|c|c|}
\hline & Cause & $\begin{array}{l}\text { Years after } \\
\text { surgery }\end{array}$ & Outcome & Currents \\
\hline Patient 1 & $\begin{array}{l}\text { Prostatic Hypertrophy } \\
\text { Urinary tract infection } \\
\text { Gallbladder stones }\end{array}$ & $\begin{array}{l}1 \\
2 \\
5\end{array}$ & $\begin{array}{l}\text { Surgically resolve } \\
\text { Surgically resolve } \\
\text { Surgically resolve }\end{array}$ & Alive \\
\hline Patient 2 & $\begin{array}{l}\text { Pneumonia } \\
\text { Road accident with cranial trauma } \\
\text { and subdural hematoma }\end{array}$ & $\begin{array}{l}2 \\
5\end{array}$ & $\begin{array}{l}\text { Medically resolve } \\
\text { Surgically resolve }\end{array}$ & Alive \\
\hline Patient 3 & Urtheral stenosis & 3 & Surgically resolve & Alive \\
\hline Patient 4 & Pneumonia & 3 & Medically resolve & Alive \\
\hline Patient 5 & $\begin{array}{l}\text { Non-haemorragic acute pancreatitis } \\
\text { of non-biliary origin }\end{array}$ & 4 & Medically resolve & Alive \\
\hline Patient 6 & Left eye cataract & 2 & Surgically & Alive \\
\hline
\end{tabular}

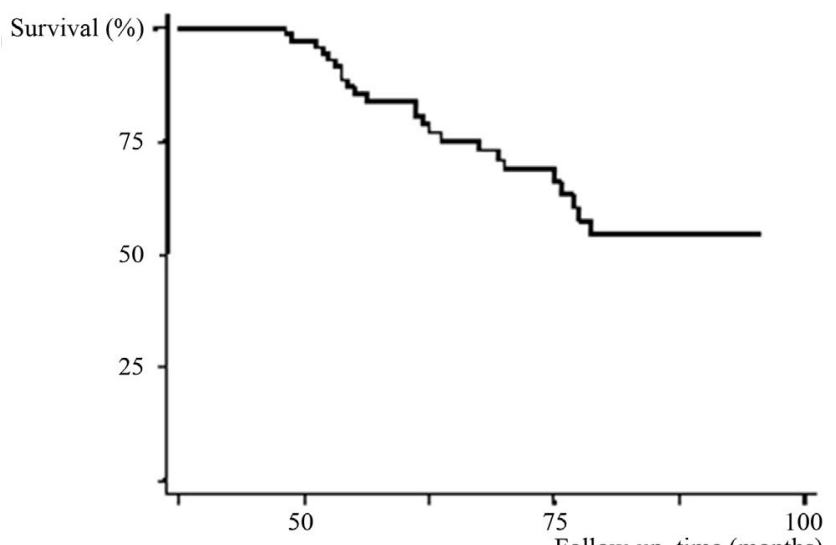

(a) of the study population Follow-up time (months)

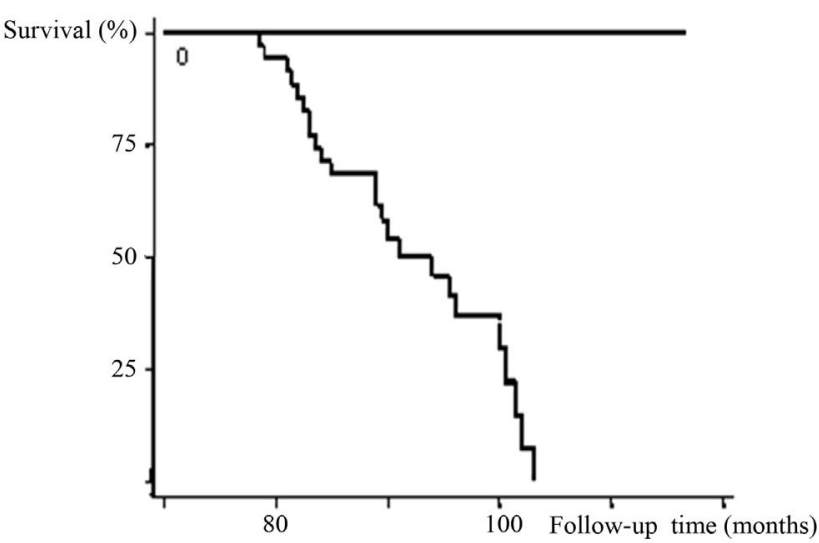

(b) by case and control

Figure 3. Kaplan-Meier survival estimates. (a) Global survival in all population (both groups); (b) Better survival in patients implanted with CD34 ${ }^{+}$PMBSC, compared with controls. 
The delivery of PBMSC by intra-myocardial injection vs intracoronary infusion has proven highly beneficial in patients with chronic ischemic heart disease [13]. The amount of injected cells seems to be essential to obtain superior results [5]. Suarez de Lezo et al. [14] reported, in acute myocardial infarction, an increase of up to $20 \%$ in the LVEF with the use of $1.7 \pm 1.3 \times 10^{7}$ PBMSC versus $2 \%-8 \%$ when lower cell concentrations were used. The excellent results that we obtained with our $3 \times$ $10^{7}$ CD $34^{+}$PBMSC preparations could be related to the presence of other immune-related cell populations in our PBMSC fractions since it is becoming clear that mesenchymal stem cells require immune cytokines to improve cardioprotection [15-17]. Actually, G-CSF, on top of enhancing stem cell liberation into the blood stream, improves left ventricular function [18]. The meta-analysis of 21 trials made by Brunskill et al. [13], showed that the major benefit of stem cell therapy occurred in patients with low LVEF baseline, however, the quantity of stem cell injected in these trials was variable and the majority of the trials were conducted in patients with acute myocardial infarcts. Ours is the first report of the long-term benefits of stem cell therapy in old myocardial infarcted patients where high PBMSC concentrations were applied.

The revascularization anastomosis was performed with beating heart because it avoids post-operatory acute cardiac failure and the use of positive inotropics and some of their secondary effects (renal failure and arrhythmias), an also because extracorporeal circulatory support induces cardiac post-operatory failure per se. Revascularization in patients with depressed ventricular function show a $6 \%$ improvement, in the best of the cases and depends on the amount of hibernate tissue. In our cases, and because the myocardial infarction is old, there was no hibernate tissue because they all had an organized scar. Revascularization was also performed in order to enhance blood flow to the old infarcted zone and conesquently, nourish the transplanted cells.

We did have 4 patients with an LVEF value $>40 \%$ but the concept of chronic ventricular failure is characterized not only by abnormal LVEF values but also by a mitral ring velocity below $10 \mathrm{~cm} / \mathrm{second} \mathrm{[19]} \mathrm{and} \mathrm{these} \mathrm{patients}$ had a $4.7 \pm 0.5 \mathrm{~cm} / \mathrm{second}$ value.

Although extensive regeneration of myocardial infarcts after direct stem cell injection, and transdifferentiation of $\mathrm{CD}_{4} 4^{+}$adult human peripheral blood cells into cardiomyocytes, has been reported [20], bone marrow cells do not transdifferentiate [21,22]. Even so, they have functional benefits: Limitation of ventricular dilatation, paracrine induction of angiogenesis, or churning out growth factors that encourage cell proliferation and/or survival [23]. Natural stem-cell mobilization to the heart [24] is extremely slow after acute and chronic myocardial infarction therefore the in situ enrichment of CD34 ${ }^{+}$ stem cells in myocardial necrotic areas is a much faster alternative. The direct injection of bone marrow cells into an organ is associated with a much greater seeding efficiency [25] and it has been demonstrated that direct intramyocardial gene therapy increase plasma CD34 ${ }^{+}$ stem cells three weeks after treatment and improve regional wall motion after three months [26]. We don't know the mechanism that enriched CD34 PBMSC use to favor ventricular function because so far, none of the transplanted patients has died. Mesenchymal stem cells promote fibroblast metalloproteinase secretion and reduce ventricular fibrosis [27]. Our results in relation to $S$, $\mathrm{A}$ and $\mathrm{E}$ waves showed that ventricular failure or abnormal filing of the left ventricle, already present before surgery, disappeared six months after stem cell surgery and continue for as long as we have followed our patients. Left ventricular dysfunction, a major determinant of prognosis, is associated with significant loss of cardiomyocytes that was previously thought to be irreversible [28]. Our LVEF and LVDV results confirm a serious improvement in left ventricle function.

As it has been shown [29] the age of the patient do not interfere with the efficacy of the treatment. The improvement in heart function was evident six months after surgery and reached its maximal value one year after surgery. The possibilities of a good response afterwards are slim or non-existent.

None of our group A patients had episodes of arrhythmia after stem cell implantation. This is because such a complication has been reported only when stem cells are implanted in or near the stellar plexus of the heart, not when they are implanted in the heart muscle.

Why is it important to implant stem cells in old myocardial infarction? Because official data from Mexico's National Center for Transplants shows that $90 \%$ of the patients with old myocardial infarction and serious cardiac insufficiency, waiting for a heart transplant, die.

\section{ACKNOWLEDGEMENTS}

The authors recognize the significant participation of Ms. Miriam Marmolejo, Head Nurse of the Hematology Service, CMN "20 de Noviembre", ISSSTE.

\section{REFERENCES}

[1] Assmus, B., Schachinger, V., Teupe, C., Britten, M., Lehmann, R., Dobert, N., Grunwald, F., Aicher, A., Urbich, C., Martin, H., Hoelzer, D., Dimmeler, S. and Zeiher, A.M. (2002) Transplantation of progenitor cells and regeneration enhancement in acute myocardial infarction (TOPCARE-AMI). Circulation, 106, 3009-3017. doi:10.1161/01.CIR.0000043246.74879.CD

[2] Strauer, B.E., Brehm, M., Zeus, T., Kostering, M., Hernandez, A., Sorg, R.V., Kogler, G. and Wernet, P. (2002) 
Repair of infarcted myocardium by autologous intracoronary mononuclear bone marrow cell transplantation in humans. Circulation, 106, 1913-1918. doi:10.1161/01.CIR.0000034046.87607.1C

[3] Kang, H.J., Kim, H.S., Koo, B.K., Park, K.W., Lee, H.Y., Sohn, D.W., Oh, B.H., Park, Y.B. and Kim, H.S. (2008) Effects of stem cell therapy with G-CSF on coronary artery after drug-eluting stent implantation in patients with acute myocardial infarction. Heart, 94, 604-609. doi:10.1136/hrt.2007.128348

[4] Singh, S., Arora, R., Handa, K., Khraisat, A., Nagajothi, N., Molnar, J. and Khosla, S. (2009) Stem cells improve left ventricular function in acute myocardial infarction. Clinical Cardiology, 32, 176-180. doi:10.1002/clc.20470

[5] Martin-Rendon, E., Brunskill, S., Hyde, C., Stanworth, S., Mathur, A. and Watt, S. (2008) Autologous bone marrow stem cells to treat acute myocardial infarction: A systematic review. European Heart Journal, 29, 1807-1818. doi:10.1093/eurheartj/ehn220

[6] Mathur, A. and Martin, J.F. (2004) Stem cells and repair of the heart. Lancet, 364, 183-192. doi:10.1016/S0140-6736(04)16632-4

[7] Tse, H.F., Kwong, Y.L., Chan, J.K., Lo, G., Ho, C.L. and Lau, C.P. (2003) Angiogenesis in ischaemic myocardium by intramyocardial autologous bone marrow mononuclear cell implantation. Lancet, 361, 47-49. doi:10.1016/S0140-6736(03)12111-3

[8] Chang, S.A., Kang, H.J., Lee, H.Y., Kim, K.H., Hur, J., Han, K.S., Park, Y.B. and Kim, H.S. (2009) Peripheral blood stem cell mobilization by granulocyte-colony stimulating factor in patients with acute and old myocardial infarction for intracoronary cell infusion. Heart, 95, 13261330. doi:10.1136/hrt.2008.148429

[9] Archundia, A., Aceves, J.L., Lopez-Hernandez, M., Alvarado, M., Rodriguez, E., Diaz Quiroz, G., Paez, A., Rojas, F.M. and Montaño, L.F. (2005) Direct cardiac injection of G-CSF mobilized bone-marrow stem-cells improves ventricular function in old myocardial infarction. Life Sciences, 78, 279-283. doi:10.1016/j.lfs.2005.04.080

[10] Lévesque, J.P., Hendy, J., Winkler, I.G., Takamatsu, Y. and Simmons, P.J. (2003) Granulocyte colony-stimulating factor induces the release in the bone marrow of proteases that cleave c-KIT receptor (CD117) from the surface of hematopoietic progenitor cells. Experimental Hematology, 31, 109-117. doi:10.1016/S0301-472X(02)01028-7

[11] Mathieu, M., Bartunek, J., El Oumeiri, B., Touibri, K., Hadad, I., Thoma, P., Metens, T., Da Costa, A.M., Mahmoudabady, M., Egrise, D., Blocklet, D., Mazouz, N., Naejje, R., Heyndrickx, G. and McEntee, K. (2009) Cell therapy with autologous bone marrow mononuclear stem cells is associated with superior cardiac recovery compared with use of nonmodified mesenchymal stem cells in a canine model of chronic myocardial infarction. The Journal of Thoracic and Cardiovascular Surgery, 138, 646653. doi:10.1016/j.jtcvs.2008.12.031

[12] Kang, H.J., Lee, H.Y., Na, S.H., Chang, S.A., Park, K.W., Kim, H.K., Kim, S.Y., Chang, H.J., Lee, W., Kang, W.J.,
Koo, B.K., Kim, Y.J., Lee, D.S., Sohn, D.W., Han, K.S., Oh, B.H., Park, Y.B. and Kim, H.S. (2006) Differential effect of intracoronary infusion of mobilized peripheral blood stem cells by granulocyte colony-stimulating factor on left ventricular function and remodeling in patients with acute myocardial infarction versus old myocardial infarction: The MAGIC Cell-3-DES randomized, controlled trial. Circulation, 114, 145-151. doi:10.1161/CIRCULATIONAHA.105.001107

[13] Brunskill, S.J., Hyde, C.J., Doree, C.J., Watt, S.M. and Martin-Rendon, E. (2009) Route of delivery and baseline left ventricular ejection fraction, key factors of bonemarrow-derived cell therapy for ischaemic heart disease. European Journal of Heart Failure, 11, 887-896. doi:10.1093/eurjhf/hfp101

[14] Suarez de Lezo, J., Herrera, C., Pan, M., Romero, M., Pavlovic, D., Segura, J., Sanchez, J., Ojeda, S. and Torres, A. (2007) Regenerative therapy in patients with a revascularized acute anterior myocardial infarction and depressed ventricular function. Revista Española de Cardiología, 60, 357-365.

[15] Herrmann, J.L., Wang, Y., Abarbanell, A.M., Well, B.R., Tan, J. and Meldrum, D.R. (2010) Precondiotioning mesenchymal stem cells with transforming growth factor-alpha improves mesenchymal stem cell-mediated cardio-protection. Shock, 33, 24-30. doi:10.1097/SHK.0b013e3181b7d137

[16] Sanganalmath, S.K., Abdel-Latif, A., Bolli, R., Xuan, Y.T. and Dawn, B. (2011) Hematopoietic cytokines for cardiac repair: Mobilization of bone marrow cells and beyond. Basic Research in Cardiology, 106, 709-733. doi:10.1007/s00395-011-0183-y

[17] Burchfield, J.S., Iwasaki, M., Koyanagi, M., Urbich, C., Rosenthal, N., Zelher, A.M. and Dimmeler, S. (2008) Interleukin-10 from transplanted bone marrow mononuclear cells contributes to cardiac protection after myocardial infarction. Circulation Research 103, 201-211. doi:10.1161/CIRCRESAHA.108.178475

[18] Kanellakis, P., Slater, N.J., Du, X.J., Bobik, A. and Curtis, D.J. (2006) Granulocyte colony-stimulating factor and stem cell factor improve endogenous repair after myocardial infarction. Cardiovascular Research, 70, 117-125. doi:10.1016/j.cardiores.2006.01.005

[19] Bartunek, J., Dimmeler, S., Drexler, H., Fernandez-Aviles, F., Galinanes, M., Janssens, S., Martin, J., Mathur, A., Menasche, P., Priori, S., Strauer, B., Tendera, M., Wijns, W. and Zeiher, A. (2006) Task force of the European Society of Cardiology. The consensus of the task force of the European Society of Cardiology concerning the clinical investigation of the use of autologous adult stem cells for repair of the heart. European Heart Journal, 27, 1338-1340. doi:10.1093/eurheartj/ehi793

[20] Yeh, E.T., Zhang, S., Wu, H.D., Korbling, M., Willerson, J.T. and Estrov, Z. (2003) Transdifferentiation of human peripheral blood CD34-enriched cell population into cardiomyocytes, endothelial cells, and smooth muscle cells in vivo. Circulation, 108, 2070-2073. doi:10.1161/01.CIR.0000099501.52718.70

[21] Balsam, L.B., Wagers, A.J., Christensen, J.L., Kofidis, T., 
Weissman, I.L. and Robbins, R.C. (2004) Haematopoietic stem cells adopt mature haematopoietic fates in ischaemic myocardium. Nature, 428, 668-673. doi:10.1038/nature02460

[22] Murry, C.E., Soonpaa, M.H., Reinecke, H., Nakajima, H., Nakajima, H.O., Rubart, M., Pasumarthi, K.B., Virag, J.I., Bartelmez, S.H., Poppa, V., Bradford, G., Dowell, J.D., Williams, D.A. and Field, L.J. (2004) Haematopoietic stem cells do not transdifferentiate into cardiac myocytes in myocardial infarcts. Nature, 428, 664-668. doi:10.1038/nature02446

[23] Menasche, P. (2004) Embryonic stem cells pace the heart. Nature Biotechnology, 22, 1237-1238. doi:10.1038/nbt1004-1237

[24] Jackson, K.A., Majka, S.M., Wang, H., Pocius, J., Hartley, C.J., Majesky, M.W., Entman, M.L., Michael, L.H., Hirschi, K.K. and Goodell, M.A. (2001) Regeneration of ischemic cardiac muscle and vascular endothelium by adult stem cells. Journal of Clinical Investigation, 107, 1395-1402. doi:10.1172/JCI12150

[25] Castello, S., Podesta, M., Menditto, V.G., Ibatici, A., Pitto, A., Figari, O., Scarpati, D., Magrassi, L., Bacigalupo, A., Piaggio, G. and Frassoni, F. (2004) Intra-bone marrow injection of bone marrow and cord blood cells: An alternative way of transplantation associated with a higher seeding efficiency. Experimental Hematology, 32, 782-787. doi:10.1016/j.exphem.2004.05.026

[26] Kastrup, J., Jorgensen, E., Ruck, A., Tagil, K., Glogar, D., Ruzyllo, W., Botker, H.E., Dudek, D., Drvota, V., Hesse, B., Thuesen, L., Blomberg, P., Gyongyosi, M. and Sylven, C. (2005) Direct intramyocardial plasmid vascular endothelial growth factor-A165 gene therapy in patients with stable severe angina pectoris. Journal of the American College of Cardiology, 45, 982-988. doi:10.1016/j.jacc.2004.12.068

[27] Mias, C., Lairez, O., Trouche, E., Roncalli, J., Calise, D., Seguelas, M.H., Ordener, C., Piercecchi-Marti, M.D., Auge, N., Salvayre, A.N., Bourin, P., Parini, A. and Cussac, D., (2009) Mesenchymal stem cells promote matrix metalloproteinase secretion by cardiac fibroblasts and reduce cardiac ventricular fibrosis after myocardial infarction. Stem Cells, 27, 2734-2743. doi:10.1002/stem.169

[28] Mozid, A.M., Arnous, S., Sammut, E.C. and Mathur, A. (2011) Stem cell therapy for heart diseases. British Medical Bulletin, 98, 143-159. doi:10.1093/bmb/ldr014

[29] Strauer, B.E., Schannwell, C.M. and Brehm, M. (2009) Therapeutic potentials of stem cells in cardiac diseases. Minerva Cardioangiologica, 57, 249-267. 